\title{
植物組織培養器内の光強度に及ぼす 栓および容器の影響
}

\author{
富士原和宏*・古在豊樹 * 中條愉利子 ${ }^{* *}$ 渡部一郎* \\ $\left(\begin{array}{c}* \text { 千葉大学園芸学部園芸環境工学研究室 } \\ * * \text { 森産業 }(\text { 株)中央研究所 }\end{array}\right)$ \\ Effects of Closures and Vessels on Light Intensities \\ in Plant Tissue Culture Vessels
Kazuhiro Fujiwara*, Toyoki Kozar*, Yuriko NaKajo**
and Ichiro WATANABE* \\ $\left(\begin{array}{c}* \text { Faculty of Horticulture, Chiba University, } \\ 648 \text { Matsudo, Matsudo, Chiba 271, Japan } \\ \text { ** Central Research Institute, Mori \& Company, Ltd., } \\ \text { 8-1 Hirai-cho, Kiryu, Gunma 376, Japan }\end{array}\right)$
}

The effects have been investigated of closures and vessels on light intensities inside closed vessels. Four kinds of closures (aluminum foil cap $\left(C_{A}\right)$, translucent polypropylene formed cap $\left(C_{P}\right)$, silicon foam rubber plug $\left(P_{S}\right)$ and transparent polycarbonate formed lid $\left.\left(L_{P}\right)\right)$ and three kinds of vessels $(47 \mathrm{~m} l$ glass flat bottom test tube, $132 \mathrm{~m} l$ glass Erlenmeyer flask and $370 \mathrm{~m} l$ polycarbonate box type vessel) were used. One straight fluorescent tube (cool white) was employed as a light source. Light intensities were measured using an illuminometer with a small photoreceptor. The measured illuminance [lx] was converted into the photon flux of $400-700$ $\mathrm{nm}$ wave lengths $\left[\mu \mathrm{mol} \cdot \mathrm{m}^{-2} \cdot \mathrm{s}^{-1}\right]$. The results can be summarized as follows:

(1) The percentage of the photon flux reduction due to the closures to the photon flux on the shelf surface was $41 \%$ for $C_{A}, 8 \%$ for $C_{P}$, and $49 \%$ for $P_{S}$ in case the test tubes were used as a vessel, and was $17 \%$ for $\mathrm{C}_{\mathrm{A}}$ and $24 \%$ for $\mathrm{P}_{\mathrm{S}}$ in case the flasks were used as a vessel.

(2) The percentage of the photon flux reduction due to the test tubes including stainless wire frame stands, and the flasks, to the photon flux on the shelf surface was $36 \%$ and $7 \%$, respectively.

(3) Mean photon flux inside the closed vessels was in the order:

$\mathrm{C}_{\mathrm{A}}-$ flask (45) $>\mathrm{P}_{\mathrm{S}}-$ flask $(41)>\mathrm{L}_{\mathrm{P}}-$ box type vessel (38)

$>C_{P}-$ test tube $(33)>C_{A}-$ test tube $(14)>P_{S}-$ test tube (9)

Values in the parentheses indicate the mean photon flux $\left[\mu \mathrm{mol} \cdot \mathrm{m}^{-2} \cdot \mathrm{s}^{-1}\right]$. The mean photon flux on the shelf surface was $59 \mu \mathrm{mol} \cdot \mathrm{m}^{-2} \cdot \mathrm{s}^{-1}$.

(4) The photon flux inside each closed vessel was dependent on each position of the closed vessel on the culture shelf, and the distribution of the photon flux varied markedly with the closure-vessel combination.

Key words: Closure, Light intensity, Plant tissue culture, Vessel.

キーワード：植物組織培養, 栓, 光強度, 容器 


\section{1. 序論}

培養器内の光強度は, 培養体の生長・発育などに影響 を及ぼすととが報告されており(例えば, Hasegawa et al., 1973 ; Seibert et al., 1975 ; Hammerschlag, 1978 ; Hunter et al., 1983 ; Schneider-Moldrickx, 1983 ; Lee et al., 1985 など), 重要な培養器内物理環 境要因の一つに挙げられているにあかかわらず，諸因子 が培養器内の光強度に及ぼす影響を調べた報告は見あた らない。また最近，シュートまたは培養小植物体の光独 立栄養培養法の研究(例えば, 富士原ら, 1987；Kozai et al., 1988a, b ; Fujiwara et al., 1988)により, それらを強光条件下で培養することの有効性が示された ことから, 培養器内の光強度に関する研究の重要性が一 層増している。

照明を必要とする植物組織培養では，一般に培養器は 培養棚 (以後, 棚)面上に直接，または試験管立を用いて 設置され，直管形蛍光灯により照明される。乙のとき培 養器内の光強度は, 直管形蛍光灯の設置本数 - 位置, 直 管形蛍光灯の分光出力, 培養器の栓 - 容器, 培養器の設 置本数・位置, および棚面・培養室内壁面の反射率など の影響を受ける。

本報告では，乙れらの光環境因子のうちの栓および容 器が，培養器内の光強度に及ぼす影響を調べた結果につ いて述べる。

\section{2. 材料および方法}

\section{1 実験装置}

本実験には，Fig.1 亿示すような実験装置（以後，装 置）を作成して用いた。装置は，構造材であるスチール 製の置棚，棚面上の空間 $(600 \mathrm{~mm} \times 1200 \mathrm{~mm} \times 410 \mathrm{~mm})$ を包囲する白色布 (反射率 : 約 72\%), 直管形白色蛍光灯

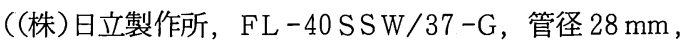
管長 $1198 \mathrm{~mm}$, 消費電力 $37 \mathrm{~W}$ ) および蛍光灯器具 (同社, PM4101 S囵) から成る。

棚面上空間を白色布で覆ったのは，その外部の光学的 環境の影響を受けずに，栓および容器のみが培養器内の 光強度に及ぼす影響を調べられるようにするためである。 一般の植物組織培養では, 棚面上空間を何等かの材料で 被覆することはない。

直管形白色蛍光灯 (以後, 蛍光灯) は, 装置の天井面の 中央に 1 本設置した。棚面から蛍光灯の中心までの距離 は $325 \mathrm{~cm}$ であった。蛍光灯への供給電力は，摺動式交 流自動電圧調整器 ( (株) 東京理工舎, ASA-10)を用い て $100 \pm 2 \mathrm{~V}$ とした。

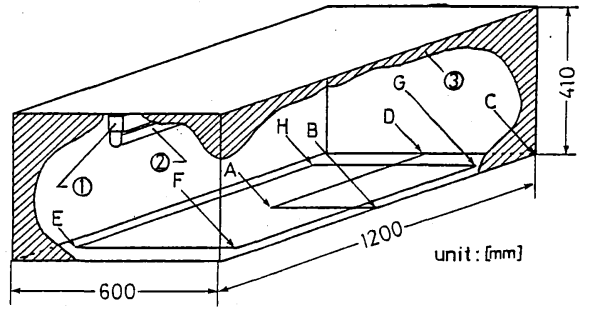

Fig. 1. Schematic diagram of an experimental device for measuring light intensities inside vessels with or without closures.

(1) fluorescent lighting fixtures, (2) fluorescent lamp, (3) white cloth for preventing unexpected light from the surroundings. Light intensities inside the vessels were measured in the area ABCD. Vessels were set up on the area EFGH.

\section{2 供試容器および栓}

容器には，ガラス製平底試験管 (三恵理化機械(株), $\phi 25 \mathrm{~mm} \times 120 \mathrm{~mm}$ ，光透過率：約 $96 \%) ，$ ガラス製三 角フラスコ (柴田化学機器工業 (株), $100 \mathrm{~m} l$, 光透過率: 約 95\%) 抢よびポリカーボネート製角型容器 (ベルディ 一(株)，プラントボックス，口部： $70 \times 70 \mathrm{~mm}$ ，底部： $60 \times 60 \mathrm{~mm}$, 高さ: $95 \mathrm{~mm}$, 容積: 約 $450 \mathrm{ml}$, 光透過 率: 約 $92 \%$ )を用いた。試験管用の栓には，アルミニウ ムフォイルキャップ(光透過率：0\%)，成型ポリプロピ レンキャップ (松本医科器機(株)，Mキャップ, 乳白色 半透明, 光透過率：約 85\%) および発泡シリコンゴムプ ラグ(信越ポリマー(株), シリコ栓 $\mathrm{T} 24$, 淡紅色, 光透 過率：0\%)の 3 種類 (Fig.2)を用い, 三角フラスコ用に は, アルミニゥムフォイルキャップおよび発泡シリコン ゴムプラグの 2 種類を用いた。アルミニウムフォイルキ ヤップは， $7 \mathrm{~cm}$ 角に切ったアルミニウム䇴（東海金属 (株)，厚さ：15 $\mu \mathrm{m} ）$ を 2 枚重ねにしたむのを容器にか

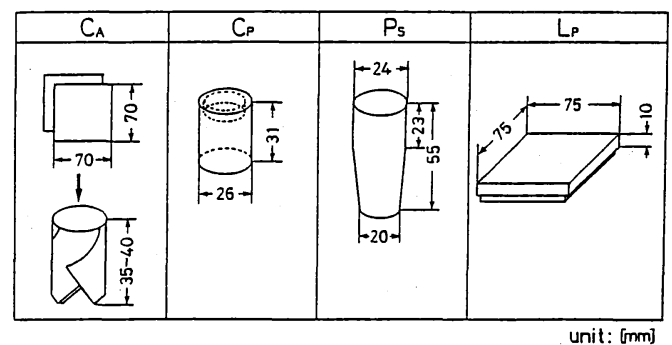

Fig. 2. Schematic diagram of the closures used in the experiment.

$\mathrm{C}_{\mathrm{A}}$ : aluminum foil cap, $\mathrm{C}_{\mathrm{P}}$ : polypropylene formed cap, $\mathrm{P}_{\mathrm{S}}$ : silicon foam rubber plug, $L_{P}$ : polycarbonate formed lid. 
ぶせて作成した。ポリカーボネート製角型容器には，専 用の成型ポリカーボネートリッド（Fig.2，光透過率： 約 95\%)を用いた。

通常，培養は容器に栓をした状態で行われるが，本実 験では, 栓および容器のそれぞれが培養器内の光強度に 及ぼす影響を調べるてとを目的としているために，容器 に栓をしない状態でも光強度の測定を行った。そてで本 論文では，古在ら（1986）の報告と同様に，容器に栓を したあのは閉栓容器, 栓をしていないあのは単に容器と 呼ぶことにした。また培養器という用語は，一般的な用 法之同様に, 容器, 閉栓容器のいずれをさす場合にあ用 いるととにする。

\section{3 培養器の棚面上への設置方法}

培養器は, Fig.1の E , F , G , Hで囲まれた範囲 (465 $\times 925 \mathrm{~mm}$ ) 内に設置した。設置本数は, 試験管の場合, 縦方向 (Fig.1のEF方向) 15 本, 横方向 (Fig.1 の EH 方向) 30 本の計 450 本, 三角フラスコでは縦方向 7 個, 横方向 14 個の計 98 個, 角型容器では縦方向 6 個, 横方 向 12 個の計 72 個であった。試験管は，ステンレスワイ ヤ一製試験管立 (三和化研工業(株)，SS型， $5 \times 10$ 本掛 け）を用いて設置し，その他の容器は棚面上に直接設置 した。

\section{4 光強度の測定法}

\subsection{1 光強度の単位}

植物組織培養に関する報告では, 光強度を照度 $[1 \mathrm{x}] や$ 放射照度 $\left[\mathrm{W} \cdot \mathrm{m}^{-2}\right\rfloor$ で表示しているあのが多い。しかし ながら, 植物と光強度の関係は, 植物体中の 1 個の光受 容体が 1 個の光量子を吸収して開始される光化学反応を 介するあのであるから, 光強度を表す単位には, 単位時 間当たりに単位面積に入射する光量子の数を表す単位で ある光量子束 $\left[\mu \mathrm{mol} \cdot \mathrm{m}^{-2} \cdot \mathrm{s}^{-1}\right]$ を用いるのが適当であ る。そてで本実験では, 光合成に影響を及ぼす波長範囲 (400-700 nm) 内の光量子を測定対象とすることにし, 光強度をその波長範囲の光量子束で表示するととにした。

2.4.2 培養器内および棚面上光強度の測定法 培養器内掞よび棚面上の光強度は, 小型の受光部 (円 柱形， $\phi 16.5 \mathrm{~mm} \times 12 \mathrm{~mm}$ )をむつ照度計 (ミノルタカメ ラ(株)， T-1M)を用いて測定した。その後, その測定 値に，供試した蛍光灯についてあらかじめ求めておいた, 照度〔1x〕から光量子束 (波長 : 400-700 nm)〔 $4 \mathrm{~mol}$ ・ $\mathrm{m}^{-2} \cdot \mathrm{s}^{-1}$ ] への換算係数を乗じて, 照度を光量子束へ変 換した。換算係数は, 供試したすべての培養器の種類に ついて $12.9 \times 10^{-3} \mu \mathrm{mol} \cdot \mathrm{m}^{-2} \cdot \mathrm{s}^{-1} \cdot 1 \mathrm{x}^{-1}$ であった。光 量子束は, 光量子計 (ライカー社, LI-190 SA) を用い て測定した。

培養器内の光強度は, 容器が試験管の場合には, 試験
管の底部を切り落として，その試験管内の底部に照度計 の小型受光部を固定したあのを，順次測定位置に移動し て測定した。容器が三角フラスコまたは角型容器の場合 には，小型受光部を容器内底部中央に接着したものを順 次移動して測定した。

培養器内の光強度は, Fig. 1 の A, B , C , D で囲まれ た範囲 $(300 \times 600 \mathrm{~mm})$ 内に設置されている培養器につ いてのみ測定した。てれは，ABを含む直線および $\mathrm{AD}$ 含む直線についてそれぞれ線対称な位置に設置されてい る培養器内の光強度は，それぞれ理論上等しいからであ る。

棚面の光強度は, 供試した各種培養器内の光強度測定 位置と同位置で測定した。

\section{3. 結果および考察}

\section{1 栓が培養器内の光強度に及ぼす影響}

\subsection{1 容器が試験管の場合}

アルミニゥムフォイルキャップ (以後, $\mathrm{C}_{\mathrm{A}}$ ), 成型ポ リプロピレンキャップ (以後, $\mathrm{C}_{\mathrm{P}}$ ) または発泡シリコン ゴムプラグ (以後, $P_{S}$ ) で栓をした試験管内の光量子束 をFig. 3 に示す。また，そのときの棚面上の光量子束を Fig.4 亿示す。図中の黒丸は, 培養器の底部中央の位置 とその培養器内の光量子束の值を示している。黒丸を結 ふ破線が切れている部分は，そてが試験管立どうしの隣 接部分であることを示している。図の右下に示されてい る数値は, 最高値 (MAX), 最小値 (MIN), 平均値 (MEAN)抽よび標準偏差 (S.D.)である。

閉栓試験管内光量子束は, 栓が $\mathrm{C}_{\mathrm{P}}$ の場合が最も高く, 次いで, $\mathrm{C}_{\mathrm{A}}, \mathrm{P}_{\mathrm{S}}$ の順であった。栓が $\mathrm{C}_{\mathrm{P}}$ である場合の 平均值は， $\mathrm{C}_{\mathrm{A}}$ および $\mathrm{P}_{\mathrm{S}}$ である場合のそれの，それぞれ 2.4 および 3.3 倍であった。

$\mathrm{C}_{\mathrm{P}}$ で栓をした試験管内の光量子束は, 蛍光灯鉛直下 （AD上）に設置された列から線分 $B C$ 側に設置された列 に向かうにつれてほぼ一定の割合で低くなった。一方, 栓が $\mathrm{C}_{\mathrm{A}}$ 扔よび $\mathrm{P}_{\mathrm{S}}$ の場合は，ADに平行で試験管立が隣 接している部分に面した位置，および周辺部で高くなり， 蛍光灯の鉛直下の列で低くなった。栓に $\mathrm{C}_{\mathrm{A}}$ と $\mathrm{P}_{\mathrm{S}}$ を用い た場合に，培養器の設置位置による光強度の分布がこの ようになったのは，栓に光透過性がないことが原因であ ると考える。

培養棚面上光量子束は， $\mathrm{A}$ の位置で最も高く， $\mathrm{BC}$ 側 および CD 側に行くにつれて徐々に低くなった。棚面上 の位置による差は培養器内のそれと比較すると小さかっ た。

次に，試験管内の光量子束を Fig. 5 亿示す。

栓のみに起因する，すなわち栓の光透過率が 100\%で 


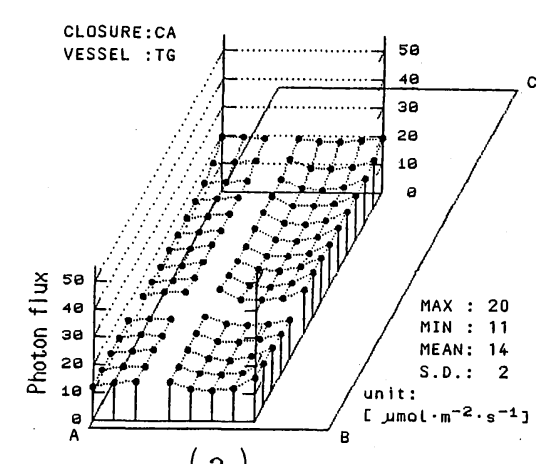

(a)

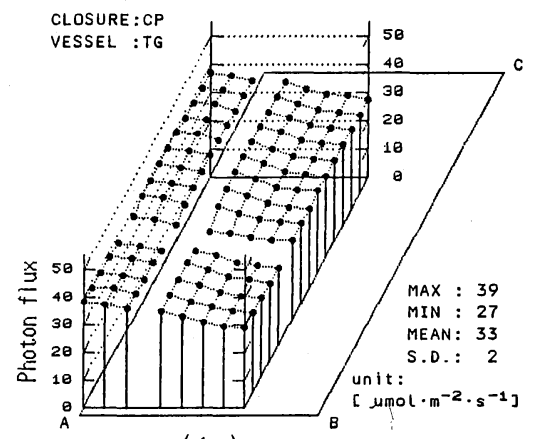

(b)

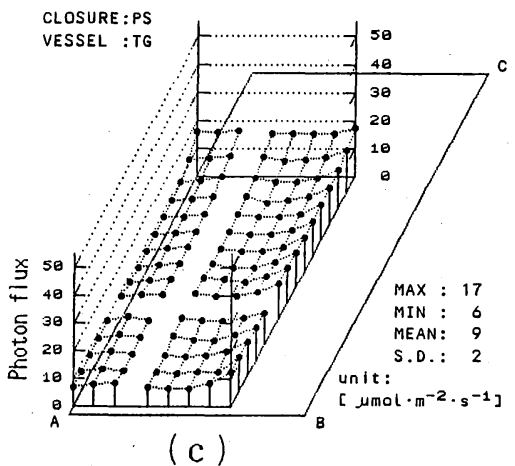

Fig. 3. Photon fluxes $(400-700 \mathrm{~nm})$ inside the glass flat bottom test tubes closed with either $C_{A}(a), C_{P}(b)$ or $P_{S}(c)$, which were set up on the area of ABCD shown in Fig.1. TG: glass flat bottom test tube, MAX: maximum, MIN: minimum, S.D.: standard deviation.

Symbols of closures are denoted in the caption of Fig. 2.

ないことが原因となって生じる閉栓試験管内光量子束の 低下量は，乙の試験管内光量子束の值加ら閉栓試験管内 の值を差し引くことにより得られる。栓のみに起因する低 下量の, 棚面上光量子束に対する率は, 栓が $\mathrm{C}_{\mathrm{A}}$ である

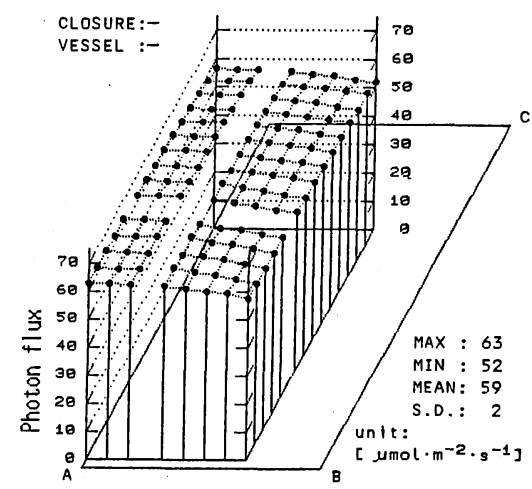

Fig. 4. Photon fluxes $(400-700 \mathrm{~nm})$ on the shelf surface.

Abbreviations are denoted in the caption of Fig. 3.

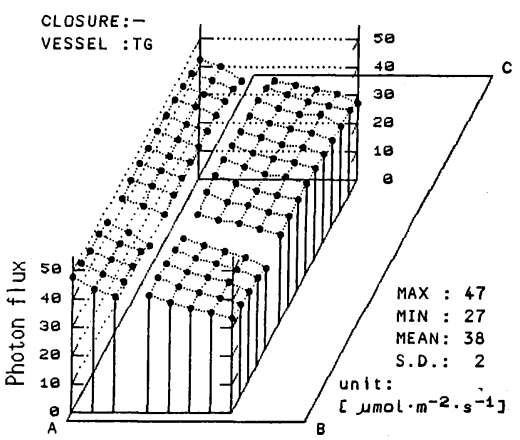

Fig. 5. Photon fluxes $(400-700 \mathrm{~nm})$ inside the glass flat bottom test tubes without closure. TG: glass flat bottom test tube.

Abbreviations are denoted in the caption of Fig. 3.

場合は， $41 \% ， \mathrm{C}_{\mathrm{P}}$ では $8 \% ， \mathrm{P}_{\mathrm{S}}$ では $49 \%$ であった。 このことは， $\mathrm{C}_{\mathrm{A}}$ または $\mathrm{P}_{\mathrm{S}}$ を用いると，照射光の半分近 くが無効となるてとを示している。

てれらの結果加ら，栓として $\mathrm{C}_{\mathrm{A}}$ または $\mathrm{P}_{\mathrm{S}}$ の代わりに $\mathrm{C}_{\mathrm{P}}$ を用いれば， あるレベルの閉栓試験管内光量子束を 得るのに必要な蛍光灯の出力は, 栓として $\mathrm{C}_{\mathrm{A}}$ または $\mathrm{P}_{\mathrm{S}}$ を用いる場合の半分以下でよいことがわかる。

\subsection{2 容器が三角フラスコの場合}

$\mathrm{C}_{\mathrm{A}}$ または $\mathrm{P}_{\mathrm{S}}$ で栓をした三角フラスコ内の光量子束を Fig. 6 亿示す。乙のときの棚面上光量子束は Fig.4 と同 様である。閉栓三角フラスコ内光量子束は, $\mathrm{C}_{\mathrm{A}}$ の場合 が $\mathrm{P}_{\mathrm{S}}$ の場合よりわずかに大であった。閉栓三角フラス コ内光量子束は, いずれの栓の場合であ蛍光灯鉛直下と $\mathrm{BC}$ 側に設置された列で低くなり， $\mathrm{BC}$ 側の列から一列 内側の列で高くなった。 


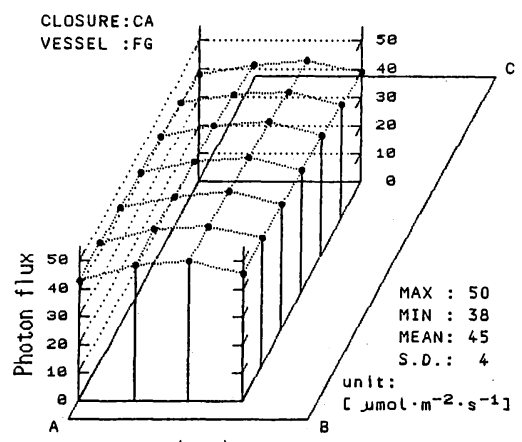

(a)

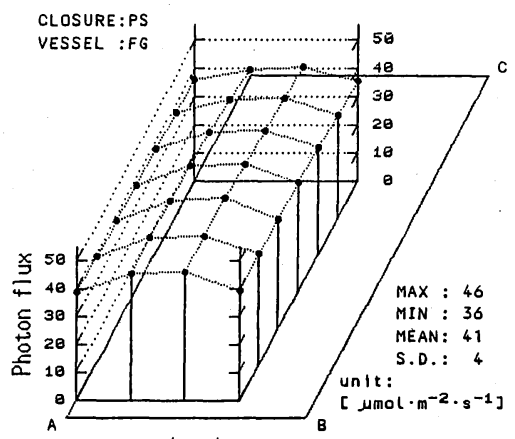

(b)

Fig. 6. Photon fluxes $(400-700 \mathrm{~nm})$ inside the glass Erlenmeyer flasks closed with $\mathrm{C}_{\mathrm{A}}$ (a) or $\mathrm{P}_{\mathrm{S}}(\dot{b})$.

FG: glass Erlenmeyer flask.

Symbols of closures and abbreviations are denoted in the caption of Fig. 2 and Fig. 3, respectively.

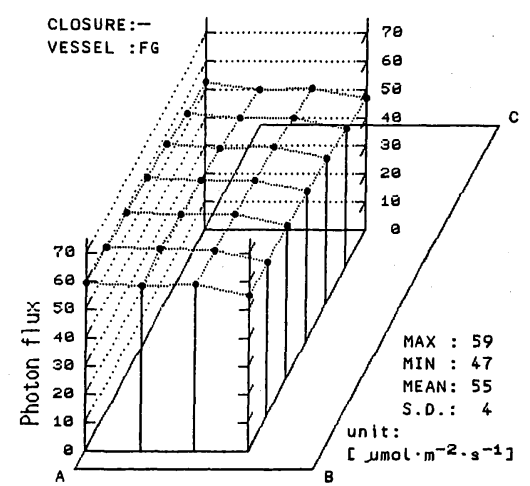

Fig. 7. Photon fluxes $(400-700 \mathrm{~nm})$ inside the glass Erlenmeyer flasks without closure. FG: glass Erlenmeyer flask.

Abbreviations are denoted in the caption of Fig. 3.

次に, 三角フラスコ内の光量子束をFig.7 亿示す。栓 のみに起因する光量子束の低下量の, 棚面上光量子束に 対する率は，栓が $\mathrm{C}_{\mathrm{A}}$ である場合は $17 \% ， \mathrm{P}_{\mathrm{S}}$ である場

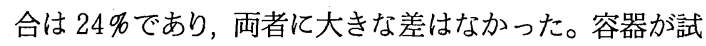
験管の場合と比較して両値が小さいのは，設置された閉 栓三角フラスコの栓と栓の間の距離が閉栓試験管の場合 よりあ大きいために，栓による遮光の程度の差が明確に 表れなかったためであると考える。

\section{2 容器が培養器内の光強度に及ぼす影響}

試験管内光量子束 (Fig. 5)の平均值は, $38 \mu \mathrm{mol} \cdot \mathrm{m}^{-2}$ $\cdot \mathrm{s}^{-1}$ であり, 三角フラスコ内光量子束 (Fig. 6)のそれ は $55 \mu \mathrm{mol} \cdot \mathrm{m}^{-2} \cdot \mathrm{s}^{-1}$ であった。棚面上光量子束の平均 值 $\left(59 \mu \mathrm{mol} \cdot \mathrm{m}^{-2} \cdot \mathrm{s}^{-1}\right)$ から両者の值を差し引いた值は, 容器に起因する低下量であるといえる。両者の棚面上に 対する低下量の率は, 前者が $36 \%$, 後者が 7\%となり, 容器に試験管を用いた場合の低下率が高い結果となった。

しかしながら，本実験では，容器として試験管を用い る場合に，通常の培養の場合と同様代試験管立を用いて いるので, 試験管内光量子束の測定結果は, 試験管自身 の影響だけでなく試験管立の遮光の影響をも受けている ことになる。したがって, 試験管自身に起因する光量子 束の低下率は, 上記の $36 \%$ よりあ低いことになる。光透 過性の高いフレームで作成された試験管立などを用いれ ば, 閉栓試験管内の光強度は多少増大すると期待される

\section{3 ポリカーボネート製閉栓角型容器内の光強} 度

ポリカーボネート製閉栓角型容器内の光量子束を Fig. 8 亿示す。閉栓角型容器内の光量子束は, $\mathrm{AD}$ 側加 $\mathrm{BC}$ 側へ，また $\mathrm{AB}$ 側から $\mathrm{CD}$ 側へと行くにつれてほぼ一定 の割合で低下するてとがわかる。

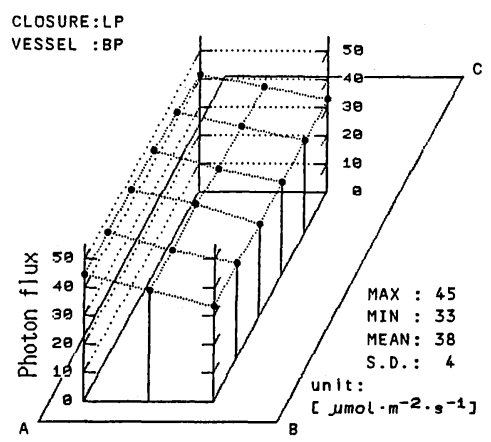

Fig. 8. Photon fluxes $(400-700 \mathrm{~nm})$ inside the closed polycarbonate box type vessels. LP: polycarbonate formed cap, BP: polycarbonate box type vessel.

Abbreviations are denoted in the caption of Fig. 3. 
また, 閉栓角型容器は, 栓および容器が光透過性の高 い透明なポリカーボネート製であるにあかかわらず，光 量子束は, 光透過性のない $\mathrm{C}_{\mathrm{A}}$ や $\mathrm{P}_{\mathrm{S}}$ を栓にあつ閉栓三角 フラスコ内のそれ(Fig.6)よりあ低かった。乙れは, 閉 栓角型容器の場合, 蛍光灯から直接閉栓容器に到達する 光 (以後, 直接光)のすべては栓の上面に入射し, そてで の反射光は上方へ向い, 反射光が周囲の閉栓容器内に直 接到達することはないのに対して, 閉栓三角フラスコの 場合, 直接光の大部分は三角フラスコの側面に到達し, そこでの反射光の一部が周囲の閉栓三角フラスコ内へ到 達するためであると考える。

このことから, 培養器内の光強度は栓および容器の光 透過率だけでなく, 両者の形状によっても大きく左右さ れることがわかる。

\section{4 種々の培養器内の光強度の比較}

本実験で供試した各種閉栓容器内光量子束の平均值の 高い順から, その栓と容器の組合せを並べると, $\mathrm{C}_{\mathrm{A}}$ 一三 角フラスコ $(76 \%), \mathrm{P}_{\mathrm{S}}$ 一三角フラスコ $(69 \%)$, 成型ポ リカーボネートリッド $\left(\mathrm{L}_{\mathrm{P}}\right)$ ーポリカーボネート製角型 容器 $(64 \%), \mathrm{C}_{\mathrm{P}}$ 一試験管 $(56 \%), \mathrm{C}_{\mathrm{A}}$ 一試験管 $(24 \%)$, $\mathrm{P}_{\mathrm{S}}$ 一試験管 $(15 \%)$, の順となった。カッコ内の数值は, 棚面上光量子束の平均值 $\left(59 \mu \mathrm{mol} \cdot \mathrm{m}^{-2} \cdot \mathrm{s}^{-1}\right)$ に対する それぞれの閉栓容器内のそれの百分率である。

以上の実験結果は, 栓と容器の組合せの選択には, 蛍 光灯の出力および設置本数の選択と同等以上の注意が必 要であることを示している。

\section{5 本実験条件下と実際の培養条件下での培養} 器内の光強度の相違

本実験では, 棚面上空間を白色布で被覆し, また培養 器を空の状態で供試している。乙れらの点は, 実際の培 養条件とは異なっている。そ乙で, 本実験条件下と実際 の培養条件下での培養器内の光強度の相違について触れ ておくことにする。

通常, 培養室内には 3-4段の棚をむつ培養棚が複数 設置されており，また培養室の内壁面の色は白色または 淡黄色であることが多い。乙のような場合, 培養室の壁 に面していない，すなわち他の培養棚に挾まれた位置に ある培養棚には, 周囲の培養棚に設置されている光源か らの照射光がかなり到達する。一方, 壁に面している培 養棚では, 培養室の内壁面からの反射光がかなり到達す る。このため, 通常の培養条件下の培養器内の光強度は, 棚面上の空間をある程度反射率の高い材料で被覆した場 合に近いと思われる。

上述したような点から推察すると, 通常の培養条件下 の培養器内の光強度は, 本実験結果よりも若干低いと思 われる。
また, 培養体が存在する培養器内の光強度は, 培養器 が空の場合よりあ当然低いであろう。特に, 茎葉が分化 した小植物体を含む培養器内の光強度は, 本実験結果よ りも 2 割程度以上低くなると推察される。

\section{6 培養器内の光環境に関する今後の課題}

培養体の生育は, 光の量である光強度だけでなく光の 質である分光組成によっても影響を受ける（例えば, Seibert et al., 1975)。今後は, 栓や容器などの光環 境因子が培養器内の分光組成に及ぼす影響をあ調べる必 要があろう。また, 照明用消費電力および培養室内の冷 房用消費電力の節減, さらには棚面上に設置された多数 の培養器内の光環境の均一化を可能とするような照明シ ステムの開発に関する研究む重要であろう。

謝 辞

本研究の一部は, 文部省科学研究費補助金 (課題番号 61480073 ) (代表者 渡部一郎)によるあのであることを 記して関係各位に謝意を表す。また, 測定結果の出力プ ログラムの作成にあたり御協力頂いた, 千葉大学園芸環 境工学研究室卒業生の井上功, 向川原稔の両氏に感謝す る。

\section{引用文献}

富士原和宏 - 古在豊樹・渡部一郎, 1987 ：培養小植物体 苗化システムの開発に関する基礎的研究 (1) 試験装置 の試作. 昭和 62 年度日本農業気象学会全国大会講演 要旨, 202-203.

Fujiwara, K., Kozai, T. and Watanabe, I., 1988: Development of a photoautotrophic tissue culture system for shoots and/or plantlets at rooting and acclimatization stages. Acta Hort., 230, 153-158.

Hammerschlag, F. A., 1978: Influence of light intensity and date of explantation on growth of geranium callus. HortScience, 13(2), 153-154.

Hasegawa, P. M., Murashige, T. and Takatori, F. H., 1973: Propagation of asparagus through shoot apex culture. II. Light and temperature requirements, transplantability of plants, and cytohistological characteristics. J. Amer. Soc. Hort. Sci., 98(2), 143-148.

Hunter, S. A., Foxe, M. J. and Hennerty, M. J., 1983: The influence of temperature and light intensity on the in vitro propagation of the strawberry (Fragaria $\mathrm{x}$ ananassa Duch.) cv. Cambrige Favourite. Acta Hort., 131, 153-161. 古在豊樹・富士原和宏・渡部一郎, 1986 : 植物組織培養 器内環境の基礎的研究 (2)栓および容器が閉栓容器内 外間のガス交換速度に及ぼす影響. 農業気象, $42(2)$, 119-127. 
Kozai, T., Koyama, Y. and Watanabe, I., 1988a: Multiplication of potato plantlets in vitro with sugar free medium under high photosynthetic photon flux. Acta Hort., 230, 121-127.

Kozai, T., Kubota, C. and Watanabe, I., 1988b: Effects of basal medium composition on the growth of carnation plantlets in auto- and mixotrophic tissue culture. Acta Hort., 230, 159166.

Lee, N., Wetzstein, H. Y. and Sommer, H. E., 1985: Effects of quantum flux density on photosynthesis and chloroplast ultrastructure in tissue- cultured plantlets and seedlings of Liquidambar styraciflua L. towards improved acclimatization and field survival. Plant Physiol., 78, 637-641. Schneider-Moldrickx, R., 1983: The influence of light quality and light intensity on regeneration of Kalanchoe-Blossfeldiana-hybrids in vitro. Acta Hort., 131, 163-170.

Seibert, M., Wetherbee, P. J. and Job., D. D., 1975: The effects of light intensity and spectral quality on growth and shoot initiation in tobacco callus. Plant Physiol., 56, 130-139. 